\title{
Preparation and Antibacterial Activity of Silver Nanoparticles Impregnated in Bacterial Cellulose
}

\author{
Luiz C. S. Maria, Ana L. C. Santos, Philippe C. Oliveira, Aline S. S. Valle \\ Departamento de Química Orgânica, UERJ
}

\author{
Hernane S. Barud, Younés Messaddeq, Sidney J. L. Ribeiro \\ Instituto de Química, UNESP
}

\begin{abstract}
A simple method was developed to load a large amount of silver nanoparticles into bacterial cellulose (BC) produced by Gluconacetobacter xylinus in a controlled manner. Due to the high electron-rich oxygen density in the BC macromolecules and the large surface area of the BC nanoporous structure as an effective nanoreactor, the in situ direct metallization technique was successfully used to synthesize $\mathrm{Ag}$ nanoparticles with an average diameter of $30 \mathrm{~nm}$ and a loading content of at least $5 \mathrm{wt}$. (\%), approximately. This novel procedure provides an easy and economical way to manufacture $\mathrm{Ag}$ nanoparticles supported on a porous membrane for various biomedical applications. These composite fibers showed nearly $100 \%$ antibacterial activity (elimination of microorganisms) against Escherichia coli because of the presence of the silver nanoparticles.
\end{abstract}

Keywords: Silver, Ag nanoparticles, bacterial cellulose, antibacterial.

\section{Introduction}

Cellulose, a linear $\beta$-1,4-linked glucose polymer, is the most abundant natural biopolymer on earth. It is synthesized by plants and also some species of bacteria. Cellulose produced by Gluconacetobacter xylinus is markedly different from cellulose obtained from trees and cotton, which is free of lignin and hemicellulose. These fibers themselves are composed of a bundle of much finer microfibrils of nanometric size ${ }^{[1,2]}$. Bacterial cellulose is an interesting material for using as a wound dressing since it provides a moist environment, resulting in better healing. However, bacterial cellulose itself has no antimicrobial activity to prevent infection ${ }^{[3]}$.

Metal nanoparticles have different properties from those of bulk metal because of their small sizes and thus these materials can be employed in various photoelectronic, catalytic, magnetic, sensor and biomedical application ${ }^{[4,5]}$. In particular, $\mathrm{Ag}$ is known to inactivate microbes by interacting with their enzymes, proteins or DNA to restrain cell proliferation or cell division. It also binds to the negativelycharged bacterial cells to change the functionality of the cell membrane, thereby preventing bacterial regeneration ${ }^{[6]}$.

Silver powders having ultrafine and uniformly distributed sizes are widely used in the chemical and electronics industries and in medicine due to their singular properties, such as high electrical and thermal conductivity, high resistance to oxidation and bactericidal action (colloidal silver). Silver is a durable (persistent) biocide with high temperature stability and very low volatility compared to other usual biocide agents, such as iodine ${ }^{[7,8]}$.
Polymer nanocomposites containing metal nanoparticles can be prepared by different methods: mechanical mixing of a polymer with metal nanoparticles; in situ polymerization of a monomer in the presence of metal nanoparticles; or in situ reduction of metal salts or complexes in a polymer ${ }^{[8,9]}$. These polymer nanocomposites have attracted a great deal of attention due to their unique properties and applications ${ }^{[10,11]}$. The literature describes many methods to prepare ultrafine silver powders ${ }^{[12-15]}$ including the formation of Ag nanoparticles attached to bacterial cellulose ${ }^{[2,3]}$.

In this work, we developed an easy method to produce composites with homogeneous size distribution of silver nanoparticles. This structure provides a robust, highlyporous and self-sustaining structure with large surface area, which is essential to facilitate incorporation of the silver ions in the metallization process to give a high silver loading content. Furthermore, the in situ direct metallization method was adopted to obtain a high loading content and strong bonding force of silver nanoparticles on the $\mathrm{BC}$ surface, thereby avoiding the $\mathrm{Ag}^{+}$contamination problem. The combination of the antibacterial efficacy of the silver nanoparticles and the biodegradability of the BC fibers in the composite fibers can make them practical for use as antimicrobial membranes in medical applications.

\section{Experimental}

\section{Materials}

The bacterial cellulose (BC) membranes were supplied by Fibrocel - Produtos Biotecnológicos Ltda. (Ibiporã, Brazil). Polyvinylpyrrolidone (PVP, MW $=29,000$ ), gelatin,

Autor para correspondência: Luiz C. S. Maria, Departamento de Química Orgânica, Instituto de Química, UERJ, Rua São Francisco Xavier, 524, 
nitric acid, silver nitrate, hydrazine, hydroxylamine, ascorbic acid, $\mathrm{NaCl}$ and $\mathrm{NaOH}$, all of P.A. degree, were commercially purchased and used as received. Aqueous solutions and bacterial suspensions were prepared using distilled deionized sterile water. Agar, tryptone and yeast extract of Bacto ${ }^{\mathrm{TM}}$, used for the microbiological culture media, were purchased from Himedia. The auxotrophic E. coli $\mathrm{OH} 5 \mathrm{~d}(\mathrm{k} 12)$ strain was taken from our laboratory stock.

\section{Ion anchorage and $\mathrm{Ag}^{+}$reduction}

The bacterial cellulose membranes were previously treated with an aqueous solution of $\mathrm{AgNO}_{3} 0.06 \mathrm{~mol} . \mathrm{L}^{-1}$ at room temperature during 24 hours. Then the membranes were thoroughly washed with distilled and deionized water until no more silver ions could be detected in the washing water by the chloride test. The $\mathrm{Ag}^{+}$containing $\mathrm{BC}$ membranes $\left(\mathrm{BC} / \mathrm{Ag}^{+}\right)$were then treated with different reducing agents in aqueous solutions containing $0.2 \% \mathrm{wt} / \mathrm{v}$ of PVP or gelatin. An aqueous solution $(0.06$ mol.L-1 $)$ of $\mathrm{NH}_{2} \mathrm{NH}_{2}, \mathrm{NH}_{2} \mathrm{OH}$ or ascorbic acid $\left(\mathrm{C}_{6} \mathrm{H}_{8} \mathrm{O}_{6}\right)$ containing $0.2 \% \mathrm{wt} / \mathrm{v}$ of PVP or gelatin was slowly added to the $\mathrm{BC} / \mathrm{Ag}^{+}$immersed in $\mathrm{PVP}$ or gelatin aqueous solution at $\mathrm{pH}$ 13-14. This addition was conducted in an ice bath (temperature around $5{ }^{\circ} \mathrm{C}$ ) for 15 minutes and the mixture was kept for a further 1 hours at room temperature. The $\mathrm{BC} / \mathrm{Ag}^{+}$became dark gray $\left(\mathrm{BC} / \mathrm{Ag}^{0}\right)$ after the reduction process. The resulting membranes were dried in air at $100{ }^{\circ} \mathrm{C}$.

\section{Characterization of composites}

$\mathrm{X}$ ray diffraction patterns (XRD) were obtained in a Siemens Kristalloflex diffractometer using nickel filtered $\mathrm{CuK} \alpha$ radiation from 4 to $70^{\circ}$ ( $2 \theta$ angle). Thermogravimetry (TG) was conducted using dried samples in SDT 2960 device from TA Instruments. Samples were heated in open alumina pans from 40 to $600{ }^{\circ} \mathrm{C}$, under an oxidant atmosphere $\left(\mathrm{O}_{2}\right)$, using flux of $50 \mathrm{~mL} / \mathrm{min}$, at a heating rate of $10{ }^{\circ} \mathrm{C} / \mathrm{min}$. The silver content of the $\mathrm{BC} / \mathrm{Ag}$ composites was estimated from the residue at $600{ }^{\circ} \mathrm{C}$. Scanning electron microscope images were obtained with an FEG-SEM JSM 6330F at the LNLS (Brazilian Synchroton Light Laboratory). Samples were coated with a 3-nm-thick carbon layer. We utilized IMAGE $\mathrm{J}$ "free software" for determination of the average of silver particle size, using a means of the fifty particles as 60.000 times of magnification.

\section{Bactericidal evaluation}

The antimicrobial activity of bacterial cellulose impregnated with silver nanoparticles was investigated against $E$. coli.

The following solution and media were prepared to study the antimicrobial activity: a) $\mathrm{NaCl}$ aqueous solution ( $2.7 \mathrm{~g}$ $\mathrm{NaCl}$ dissolved in $300 \mathrm{~mL}$ of distilled water), sterilized by autoclaving at $120^{\circ} \mathrm{C}$ for 20 minutes; b) culture medium (LB) containing $1.0 \mathrm{~g} \mathrm{NaCl}, 1.0 \mathrm{~g}$ tryptone, $0.5 \mathrm{~g}$ yeast extract of Bacto $^{\mathrm{TM}}$ and $100 \mathrm{~mL}$ distilled water, sterilized by autoclaving at $120{ }^{\circ} \mathrm{C}$ for 20 minutes; and c) solid Luria-Bertani (LB) medium, used to prepare Petri dishes containing $3 \mathrm{~g} \mathrm{NaCl}$, $3 \mathrm{~g}$ tryptone, $1.5 \mathrm{~g}$ yeast extract of Bacto $^{\mathrm{TM}}, 4.5 \mathrm{~g}$ Agar and $300 \mathrm{~mL}$ distilled water. The solid Luria-Bertani (LB) medium was sterilized by autoclaving at $120^{\circ} \mathrm{C}$ for 20 minutes.

An aliquot $(100 \mu \mathrm{L})$ of the bacterial suspension prepared previously was transferred to a test tube with $9.9 \mathrm{~mL}$ of lysogenic broth medium (LB) and homogenized. This tube contained a concentration of $10^{7}$ cells. $\mathrm{mL}^{-1}$. This bacterial suspension was diluted in a saline solution to obtain a suspension containing about $10^{5}$ cells.mL $\mathrm{mL}^{-1}$. Aliquots of $1000 \mu \mathrm{L}$ of the suspension containing about $10^{5}$ cells.mL $\mathrm{mL}^{-1}$ were transferred to sterile test tubes containing the samples. The test tubes were incubated in a stirring incubator at $37{ }^{\circ} \mathrm{C}$ and stirred at $120 \mathrm{rpm}$ for 24 hours. After incubation, the content of the tubes was transferred to four Erlenmeyer flasks filled with $50 \mathrm{~mL}$ of sterile $\mathrm{NaCl}$ aqueous solution at $0.9 \%$. An aliquot $(100 \mu \mathrm{L})$ of the content of each Erlenmeyer flask was transferred to a microtube filled with $900 \mu \mathrm{L}$ of sterile $\mathrm{NaCl}$ aqueous solution. The microtubes were then vortexed. This dilution sequence was repeated four times to obtain four dilutions. Aliquots $(100 \mu \mathrm{L})$ of these dilutions were then spread on a nutrient agar plate and incubated at $37{ }^{\circ} \mathrm{C}$ for 24 hours, after which the colony-forming units (CFU) were counted and the average was taken of the three plates corresponding to a particular sample. The antibacterial activity of the silver nanoparticles impregnated in bacterial cellulose was determined at different concentrations $\left(10^{3}, 10^{4}\right.$, $10^{5}, 10^{6}$ and $10^{7}$ cells. $\mathrm{mL}^{-1}$ ). The experiments were carried out in triplicate. Statistical analysis was performed using Student's $t$-test and the percentage reduction in bacterial count was calculated by the Equation 1:

[(viable CFU at 0 hour - viable $\mathrm{CFU}$ at 24 hours)

/viable CFU at 0 hour] $\times 100 \%$

\section{Results and Discussion}

As shown in Figure 1, bacterial cellulose (BC) is an oxygen-rich natural carbohydrate (polysaccharide) consisting of the anhydroglucose units joined by an oxygen bond to form a linear molecular chain ${ }^{[16,17]}$. Electrostatic interactions (i.e., ion-dipole) are expected to take place between the $\mathrm{Ag}$ ions and the electron-rich oxygen atoms of the $\mathrm{BC}$ matrix resulting from the hydroxyl and ether. Figure 1 shows a schematic representation of the procedure for preparing the $\mathrm{BC}$ nanofibrillar hydrogel coated with Ag nanoparticles. The negatively-charged $\mathrm{BC}$ nanofibril attracts the $\mathrm{Ag}$ ions via electrostatic interactions and the $\mathrm{Ag}$ ions are thus kept stably and uniformly distributed on the $\mathrm{BC}$ nanofibril surface. When the $\mathrm{BC}$ nanofibrils with $\mathrm{Ag}$ ions are immersed in the reducing agent solution in the presence of a protective colloid (PVP or gelatin), the $\mathrm{Ag}$ ions are reduced to $\mathrm{Ag}^{0}$ particles, which are stabilized at the ion selective sites of the BC surface without becoming coagulated ${ }^{[18]}$. 

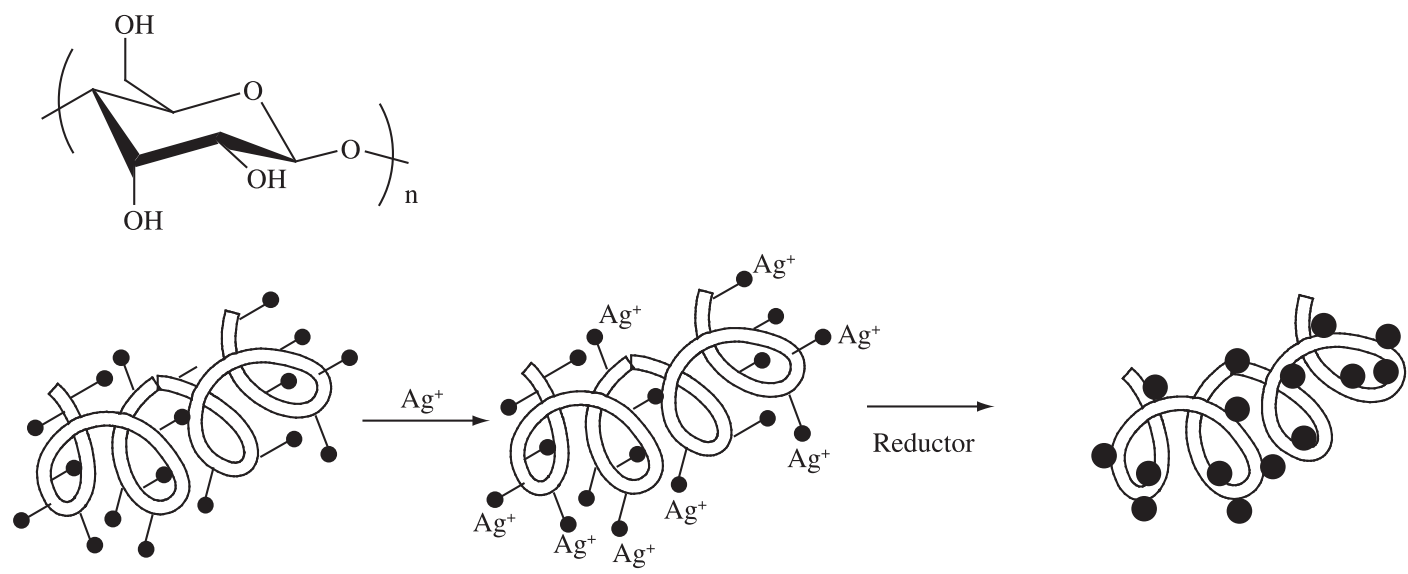

= group containing oxygen on $\mathrm{BC}$

$=\mathrm{Ag}$ nanoparticle

Figure 1. Representation of the production of the Ag nanoparticles on $\mathrm{BC}$ nanofibrillar structure through the in situ metallization method.

Table 1. Silver content and average particle sizes of the BC/Ag composites.

\begin{tabular}{|c|c|c|c|}
\hline Composite & Description of the samples & $\operatorname{Ag} \%^{a}$ & Average of silver particle size $(\mathrm{nm})^{\mathrm{b}}$ \\
\hline $\mathrm{COA}$ & $\mathrm{BC} / \mathrm{Ag}^{0}$ obtained with $\mathrm{C}_{6} \mathrm{H}_{8} \mathrm{O}_{6}$ without colloid protector & 25.0 & 85 \\
\hline $\mathrm{C} 0 \mathrm{Z}$ & BC/Ag ${ }^{0}$ obtained with $\mathrm{NH}_{2} \mathrm{NH}_{2}$ without colloid protector & 22.4 & 125 \\
\hline $\mathrm{COX}$ & $\mathrm{BC} / \mathrm{Ag}^{0}$ obtained with $\mathrm{NH}_{2} \mathrm{OH}$ without colloid protector & 11.3 & 130 \\
\hline CGA & $\mathrm{BC} / \mathrm{Ag}^{0}$ obtained with $\mathrm{C}_{6} \mathrm{H}_{8} \mathrm{O}_{6}$ and gelatin & 19.6 & 58 \\
\hline CGZ & $\mathrm{BC} / \mathrm{Ag}^{0}$ obtained with $\mathrm{NH}_{2} \mathrm{NH}_{2}$ and gelatin & 4.9 & 52 \\
\hline CGX & $\mathrm{BC} / \mathrm{Ag}^{0}$ obtained with $\mathrm{NH}_{2} \mathrm{OH}$ and gelatin & 7.8 & 30 \\
\hline $\mathrm{CPA}$ & $\mathrm{BC} / \mathrm{Ag}^{0}$ obtained with $\mathrm{C}_{6} \mathrm{H}_{8} \mathrm{O}_{6}$ and PVP & 6.0 & 38 \\
\hline $\mathrm{CPZ}$ & $\mathrm{BC} / \mathrm{Ag}^{0}$ obtained with $\mathrm{NH}_{2} \mathrm{NH}_{2}$ and PVP & 4.9 & 77 \\
\hline CPX & $\mathrm{BC} / \mathrm{Ag}^{0}$ obtained with $\mathrm{NH}_{2} \mathrm{OH}$ and PVP & 8.0 & 82 \\
\hline
\end{tabular}

${ }^{\mathrm{a}}$ Estimated from the residue from thermogravimetry at $600^{\circ} \mathrm{C}$; and ${ }^{\mathrm{b}}$ Determined by microscopic analysis; $\mathrm{PVP}=$ polyvinylpyrrolidone.

Table 1 shows the average particle size values measured by microscopic analysis and the silver content estimated from the residue obtained from thermogravimetry analysis at $600{ }^{\circ} \mathrm{C}$. In general, we observed that the silver particles obtained in the presence of a protective colloid (mostly gelatin) were smaller than those obtained without it (namely, $\mathrm{C} 0 \mathrm{~A}, \mathrm{COZ}$ and $\mathrm{COX}$ ). This indicates that these compounds affect the growth of silver particles. Indeed, the use of the protective colloid in nanoparticle synthesis is necessary to stabilize the particles and keep them from agglomerating. As can be seen in Table 1, smaller silver particles were obtained when gelatin was employed compared to those prepared with PVP. Probably the better gelatin protection action was due to its chemical structure, which contains many $-\mathrm{COOH}$ e $-\mathrm{NH}_{2}$ groups. The free electron pairs of these $\mathrm{O}$ and $\mathrm{N}$ atoms could coordinate with the empty $s p$. orbital of $\mathrm{Ag}^{+}$. This complex formed between $\mathrm{Ag}^{+}$and gelatin could promote particle nucleation $^{[19,20]}$.

The interaction among the protective colloid (PVP or gelatin), $\mathrm{Ag}^{+}$(coordination) and metallic surface (sorption phenomenon) may produce a protective colloidal layer, preventing the particles from agglomerating. It is also possible that the amount of PVP was not enough to produce an effective protective effect.

Characteristic grey-colored homogenous membranes were obtained in all $\mathrm{BC}-\mathrm{Ag}$ composites. $\mathrm{X}$ ray diffraction for all BC-Ag composites (not shown here) confirmed silver particle formation on to $\mathrm{BC}$ microfibril. All sample XRD patterns displayed broad diffraction peaks at $15^{\circ}$ and $22.5^{\circ}$, which are assigned to the characteristic interplane distances of cellulose $1_{\alpha}$ and $1_{\beta}$ phases $\left(100_{1 \alpha}, 110_{1 \beta}\right.$ and $010_{1 \beta}$ planes at $15^{\circ}$ and $110_{1 \alpha}$ and $200_{1 \beta}$ at $\left.22.5^{\circ}\right)^{[2,18]}$.

A typical Ag cubic phase was clearly identified in all the samples from the diffraction peaks at $38.1^{\circ}, 44.3^{\circ}, 64.4^{\circ}$ [crystallographic planes (111) and (200), (220), respectively], clearly indicating the face centered cubic (FCC) structure of the silver ${ }^{[21]}$.

We conducted SEM-FEG measurements to study the morphology of BC-Ag composites. Figure 2 shows SEM images of the pure bacterial cellulose membrane (Figure 2a). One representative BC-Ag composite prepared with ascorbic acid used as reducing agent without protective agent (Figure 2b), other composite produced by the reduction with hydroxylamine using gelatin as colloid protector 
(Figures 2c, d) and other BC-Ag composite produced with ascorbic acid using gelatin as colloid protector (Figures 2e, f) are analyzed.

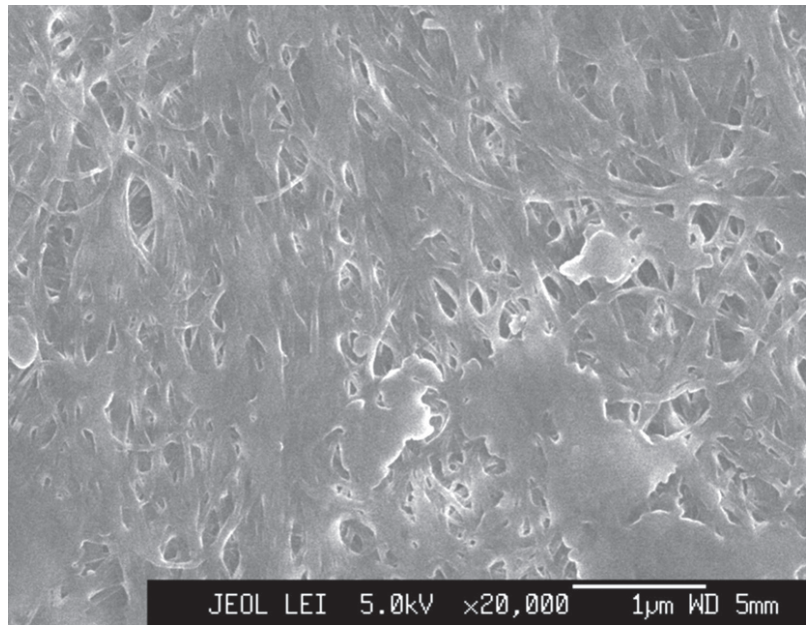

(a)

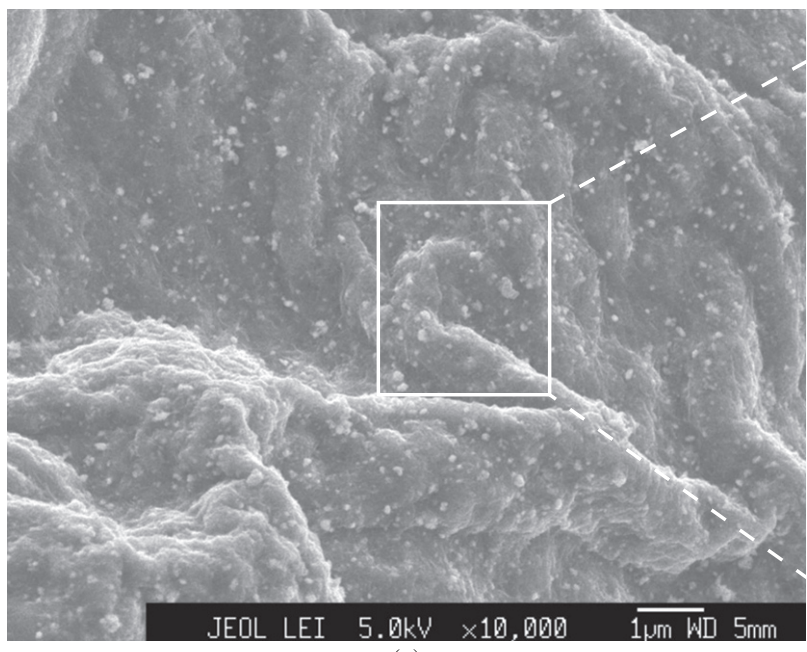

(c)

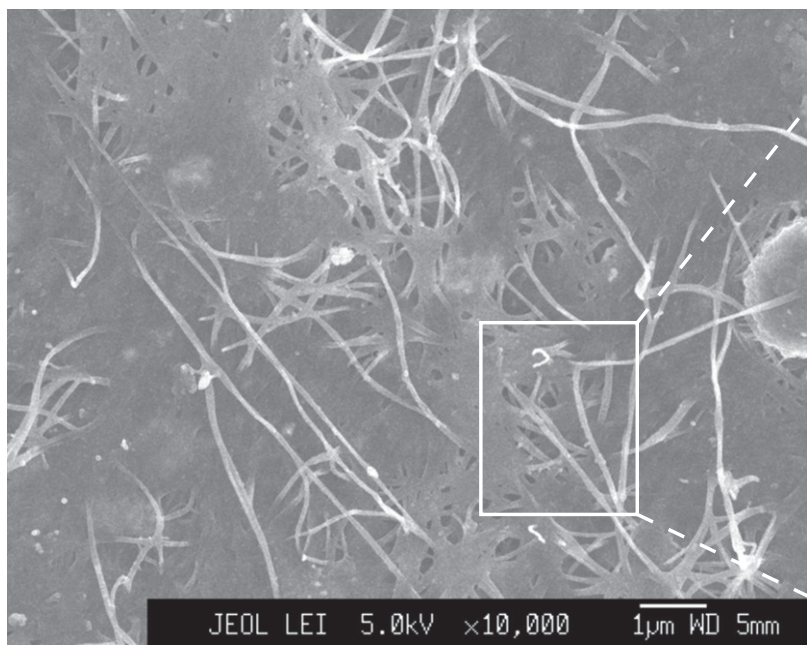

(e)
SEM images of the surface of the dried BC membrane (Figure 2a) show a reticulated structure formed by aggregates of extended semicrystalline cellulose chains in an ultrafine

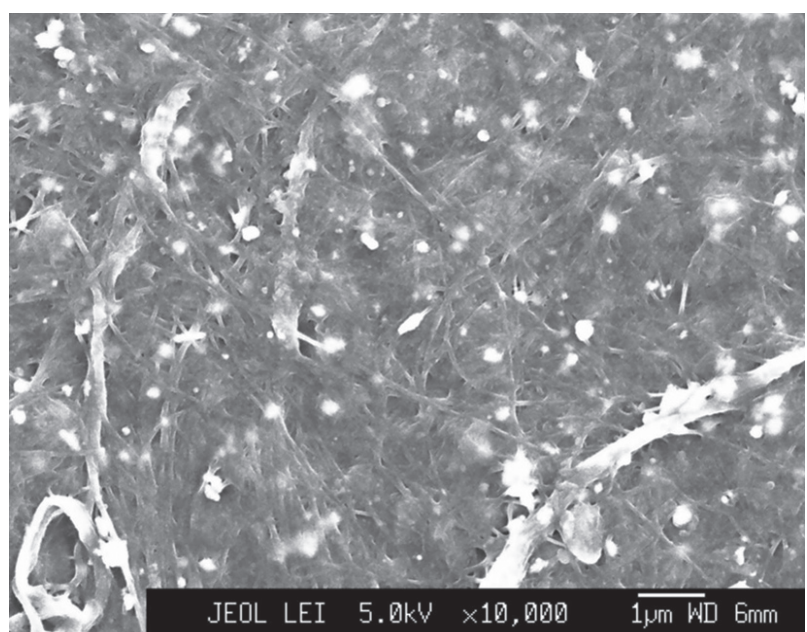

(b)

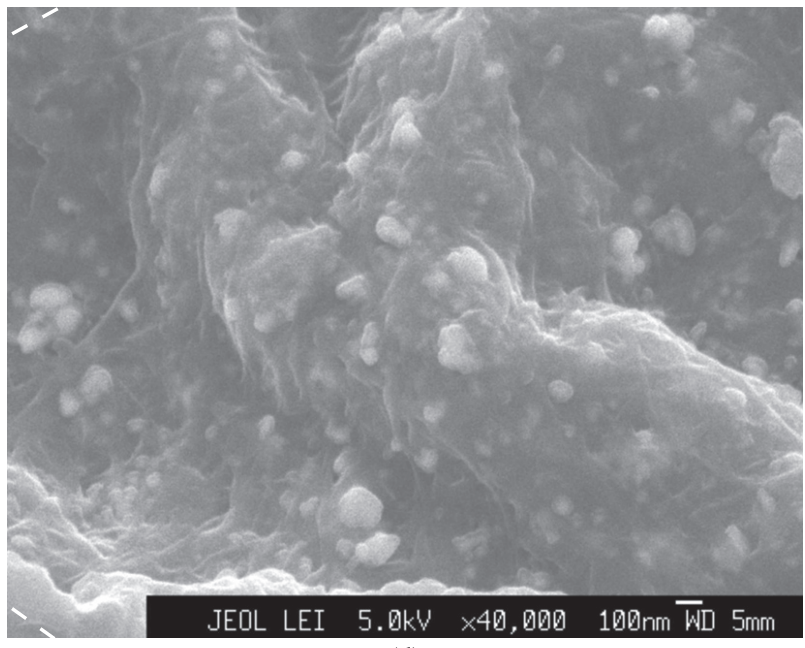

(d)



(f)

Figure 2. SEM micrographs of the pure bacterial cellulose (BC) membrane (a), representative BC-Ag composite prepared with ascorbic acid used as reducing agent without protective agent (b); SEM images of BC-Ag composite produced by the reduction with hydroxylamine using gelatin as colloid protector (c, d); and SEM images of BC-Ag composite produced by the reduction with ascorbic acid using gelatin as colloid protector (e and $\mathrm{f}$ ). 
network structure consisting of long nanofibers about $10 \mathrm{~nm}$ thick and $50 \mathrm{~nm}$ wide. Figure $2 \mathrm{~b}$ is a representative SEM image of the bacterial cellulose membranes obtained from the $\mathrm{Ag}^{+}$reduction with ascorbic acid without colloid protector $(\mathrm{C} 0 \mathrm{~A})$. This image reveals non-homogeneous silver nanoparticles attached on to the $\mathrm{BC}$ microfibril.

The redox potentials of the three reducing agents employed are more negative than those of silver ions ${ }^{[22]}$, suggesting easy reduction to $\mathrm{Ag}^{0}$, which was indeed observed under the experimental conditions used.

Figures 2c, d show the SEM micrographs of typical silver composite produced on $\mathrm{BC}$ membrane using hydroxylamine as the reducing agent and gelatin as colloid protector; and Figures 2e, f show the SEM micrographs of typical silver composite produced on $\mathrm{BC}$ membrane using ascorbic acid as the reducing agent and gelatin as colloid protector. A general view of the synthesized composite membranes shows silver nanoparticles attached on $\mathrm{BC}$ microfibrills. The metallic silver and $\mathrm{BC}$ regions were analyzed by backscattered electron detection. Since the contrast in this kind of image formation is obtained by differences in the atomic number of the elements in the sample, it was possible to distinguish the silver distribution on the microfibrils. The SEM-FEG micrograph (Figure 2f) shows that the primary particle size of silver in the colloid is around $40 \mathrm{~nm}$. As a rule, these particles were clustered with a size up to $30 \mathrm{~nm}$ as isolated round particles. On the other hand, others composites had silver particles as agglomerates larger than $100 \mathrm{~nm}$. These images indicate that the combination of gelatin and ascorbic acid is able to control the growth and morphology of silver nanoparticles.

In this metallization method, the hydroxyl and ether groups combined with the colloid protector not only anchor the silver ions to the $\mathrm{BC}$ nanofibrils via ion-dipole interactions, they also stabilize the Ag metal nanoparticles at the selective sites of the $\mathrm{BC}$ surface without becoming coagulated ${ }^{[5,17,23]}$.

Figure 2 show that the $\mathrm{Ag}$ particles on the $\mathrm{BC}$ composite surface have two different features. It is possible to see spherical nanoparticles (Figures 2c, d) randomly dispersed on the $\mathrm{BC}$ surface of composites prepared by reduction with hydroxylamine in the presence of gelatin. Actually, few clusters of Ag particles were observed on preferential regions of their surfaces. These micrographs shows clearly that gelatin has an important role in keeping the silver particles from coalescing in the CGX composite compared to the composites prepared without it (Figure 2b). On the other hand, dissimilar profiles of silver particles were observed on the $\mathrm{BC}$ composites prepared with PVP as colloid protector with the other reducing agents (namely hydrazine and hydroxylamine). In this case, the silver particles agglomerated in clusters larger than $70 \mathrm{~nm}$ (Table 1) with no defined morphology.

To evaluate the bactericidal activity purely due to the silver included in the composites, we neutralized the crude $\mathrm{BC}$ and the composites with $\mathrm{Na}_{2} \mathrm{CO}_{3}$ aqueous solution ( $2 \% \mathrm{wt}$ ) for 24 hours, followed by a thorough washing of the cellulose with
Table 2. E. coli content in the initial suspensions and decrease in $\mathrm{CFU} \%$ after contact with $\mathrm{BC} / \mathrm{Ag}$ composites.

\begin{tabular}{cccc}
\hline $\begin{array}{c}\text { Initial } \\
\text { concentration } \\
\text { (cells.mL }\end{array}$ & \multicolumn{3}{c}{ Decreasing $(\mathbf{C F U} \%)^{\mathbf{a}}$} \\
\cline { 2 - 4 } & $\mathbf{C O X}$ & $\mathbf{C P X}$ & $\mathbf{C G X}$ \\
\hline $0^{*}$ & - & - & - \\
$10^{3}$ & 17 & 24 & 100 \\
$10^{4}$ & 10 & 20 & 100 \\
$10^{5}$ & 8 & 15 & 100 \\
$10^{6}$ & 0 & 0 & 100 \\
\hline
\end{tabular}

${ }^{\text {a}}$ Results are expressed in percentage of residual bacterial concentration. Standard deviation $=\mathrm{CFU} 5 \%$. E. coli cultures of $\mathrm{OH} 5 \mathrm{~d}(\mathrm{k} 12)$ (wild type) in the mid exponential phase of growth were prepared in Luria-Bertani (LB) medium at $37{ }^{\circ} \mathrm{C}$ during 24 hours; $\mathrm{C} 0 \mathrm{X}=$ composite prepared without colloid protector and reduced with hydroxylamine, $\mathrm{CPX}=$ composite prepared with PVP as colloid protector and reduced with hydroxylamine, CGX = composite prepared with gelatin as colloid protector and reduced with hydroxylamine; *sterile $\mathrm{NaCl}$ aqueous solution at $0.9 \%$ wt. $(\%)$.

deionized water until neutrality. We also evaluated the $\mathrm{Ag}^{+}$ release by the chloride test. All materials were immersed in a sterile $\mathrm{NaCl}$ aqueous solution during 24 hours in a magnetic stirrer aiming to evaluate the possible contamination. Then $100 \mu \mathrm{L}$ of each of these cell suspensions was seeded onto LB agar using a surface spread plate technique and no bacterial colony (CFU) was observed (see first line of Table 2).

The bacterial activity of the $\mathrm{BC} / \mathrm{Ag}^{0}$ (COX, CPX and CGX) composites was available against suspensions containing known concentrations of $E$. coli. The results are summarized in Table 2. The CGX composite demonstrated strong antibacterial activity, since the CFU reduction percentage was $100 \%$ for suspensions containing up to $10^{7}$ cells. $\mathrm{mL}^{-1}$. On the other hand, the COX and CPX composites did not exhibit significant activity, even though these materials have higher silver content than the CGX composite. In fact, even the COX and CPX composites, which have higher silver content (11.3 and $8.0 \%$, respectively) than the CGX composite (7.8\%), showed lower bactericidal activity (from 8 to $17 \%$ for the C0X, from 15 to $24 \%$ for the CPX and no activity for $10^{6}$ and $10^{7}$ cells. $\mathrm{mL}^{-1}$ ) compared to the CGX composite. This discrepancy can be explained by the great difference of the particle size in the $\mathrm{BC}-\mathrm{Ag}$ composites. $\mathrm{BC}-\mathrm{Ag}$ (CGX) is the composite that has the smallest particle size $(30 \mathrm{~nm})$, and it had better bactericidal effect. The results strongly suggest that the bactericidal properties of BC-Ag composites depend on the silver particle size.

\section{Conclusions}

The distribution of the silver particles and their sizes in the composites depend on the combination of the type of reducing and colloid protector agents used during their synthesis. It seems that the $\mathrm{Ag}^{+}$in the form of ionic conglomerate present on the $\mathrm{BC}$ membrane or coordinated silver complexes with colloid protector favors the growth of submicron-sized 
silver particles, and silver colloids are beneficial for the nucleation of silver nanoparticles by reduction with ascorbic acid, hydrazine and hydroxylamine. The colloid protector, particularly gelatin, has an important role in keeping the silver particles from coalescing and controlling the size of the particles anchored on the $\mathrm{BC}$ membrane. The strong bactericidal activity of the Ag composites based on bacterial cellulose is attributed to the action of silver nanoparticles obtained when a combination of hydroxylamine as reducing agent and gelatin as protective colloid was employed.

\section{Acknowledgments}

We acknowledge the financial support of the Rio de Janeiro State Research Support Foundation - FAPERJ (Process APQ1 E-26/171.289/2006), São Paulo State Research Support Foundation - FAPESP, Office to Improve University Research - CAPES and National Scientific and Technological Research Council - CNPq (Process 473687/2008-9). We also thank the Electron Microscopy Laboratory/National Synchrotron Light Laboratory (LME/LNLS) for technical support during the electron microscopy work and the company Fibrocel Produtos Biotecnológicos Ltda. for supplying the bacterial cellulose membranes

\section{References}

1. Klemm, D.; Heublein, B.; Fink, H. P. \& Bohn, A. Angew. Chem. Int., 44, p.3358 (2005).

2. Barud, H. S.; Ribeiro, C. A.; Crespi, M. S.; Martines, M. A. U.; Dexpert-Ghys, J.; Marques, R. F. C.; Messaddeq, Y. \& Ribeiro, S. J. L. - J. Therm. Anal. Calorim., 87, p.815 (2007).

3. Maneerung, T.; Tokura, S. \& Rujiravanit, R. - Carbohydr. Polim., 72, p.43 (2008).

4. Dai, J. \& Bruening, M. L. - Nano Lett., 2, p.497 (2002).

5. Nguyen, D. L.; Youngkwan, L. \& Jae-Do, N. - Eur. Polym. J., 44, p.3116 (2008).

6. Hong, K. H. - Polym. Eng. Sci., 47, p.43 (2007).

7. Santa Maria, L. C.; Aguiar, M. R. M. P.; Costa, M. A. S.; Valle, A. S. S.; Soares, J. G. M.; Souza, J. D. C. \& Wang, S. H. - Mater. Lett., 61, p.2993 (2007).
8. Santa Maria, L. C.; Souza, J. D. C.; Aguiar, M. R. M. P.; Wang, S. H.; Mazzei, J. L.; Felzenszwalb, I. \& Amico, S. C. - J. Appl. Polym. Sci., 107, p.1879 (2008).

9. Barud, H. S.; Barrios, C.; Regiani, T.; Marques, R. F. C.; Verelst, M.; Dexpert-Ghys, J.; Messaddeq, Y. \& Ribeiro, S. J. L. - Mater. Sci. Eng. C, 28, p.515 (2008).

10. Shiraishi, Y. \& Toshima, N. - Col. Surf. A, 169, p.59 (2000).

11. Schierholz, J. M.; Lucas, L. J.; Rump, A. \& Pulverer, G. - J. Hosp. Infect., 40, p.257 (1998).

12. Shanmugam, S.; Viswanathan, B. \& Varadarajan, T. K. Mater. Chem. Phys., 95, p.51 (2006).

13. Nersisyan, H. H.; Lee, J. H.; Son, H. T.; Won, C. W. \& Maeng, D. Y. - Mater. Res. Bul., 38, p.949 (2003).

14. Zhang, Z.; Zhang, L.; Wang, S.; Chen, W. \& Lei Y. Polymer, 42, p.8315 (2001).

15. Chou, K. S. \& Ren, C. Y. - Mater. Chem. Phys., 64, p. 241 (2000).

16. Edgar, K. J.; Buchanan, C. M.; Debenham, J. S.; Rundquist, P. A.; Seiler B. D.; Shelton, M. C. \& Tindall, D. - Prog. Polym. Sci., 26, p.1605 (2001).

17. He, J.; Kunitake, T. \& Nakao, A. - Chem. Mater., 15, p.4401 (2003).

18. Santa Maria, L. C.; Santos, A. L. C.; Oliveira, P. C.; Barud, H. S.; Messaddeq, Y. \& Ribeiro, S. J. L.- Mater. Lett., 63, p.797 (2009).

19. Yiwei, A.; Yunxia, Y.; Shuanglong, Y.; Lihua, D. \& Guorong, C. - Mater. Chem. Phys., 104, p.158 (2007).

20. Rujitanaroj, P.; Pimpha, N. \& Supaphol, P. - Polymer, 49, p.4723 (2008).

21. Jiang, G. H.; Wang, L.; Chen, T.; Yu, H. J. \& Wang, J. J. J. Mater. Sci., p.1681 (2005).

22. Lurie, J. - "Handbook of Analytical Chemistry", Mir Publishers, Moscow (1975).

23. He, J.; Ichinose, I.; Kunitake, T. \& Nakao, A. - Langmuir, 18, p.10005 (2002).

Enviado: 07/09/09

Reenviado: 02/12/09

Aceito: $14 / 12 / 09$

DOI: $10.1590 / \mathrm{S} 0104-14282010005000001$ 